\title{
Organ commercialism, trafficking and transplant tourism
}

\author{
MUNEET KAUR SAHI, SUNIL SHROFF, SUMANA NAVIN, PALLAVI KUMAR
}

\begin{abstract}
The gap between demand and supply of organs continues to widen worldwide, encouraging transplant commercialism. While solid organ commerce is most prevalent in impoverished countries, commercialisation of body parts such as tissues is prevalent in economically developed countries. A number of international legal instruments and transplant societies define, condemn, and criminalise these practices and have issued statements related to organ commercialism. In contrast, limited attention has been paid to illicit and unethical activities associated with the procurement and clinical use of tissues. In India, The Transplantation of Human Organs (Amendment) Act, 2011, has taken multiple measures to combat organ and tissue commerce and as a result the number of such instances seems to be on the decline. However, the fight against unethical organ procurement through the internet and the social media is challenging and requires the cooperation of global bodies.
\end{abstract}

Keywords: Organ trade, Declaration of Istanbul, tissue commerce, organ transplants, transplant tourism

\section{Introduction}

The gap between demand and supply of organs continues to widen worldwide. Organ scarcity has led to transplant commercialism, more so in resource-poor countries (1). However, equally disturbing is the commercialisation of tissue, where the demand and supply problem has largely been overcome; in fact, internationally there are certain types of tissues that are available in excess of the demand (2). A

Authors: Muneet Kaur Sahi (corresponding author muneetsahi@mohanfoundation.org), Programme Manager, MOHAN Foundation, Sushant Lok - I, Gurugram-122 002 Haryana, INDIA; Sunil Shroff (shroff@mohanfoundation.org), Managing Trustee, MOHAN Foundation, Toshniwal Building, 267, Kilpauk Garden Road, Chennai-600 010 Tamil Nadu INDIA; Sumana Navin (sumana@mohanfoundation.org), Course Director, MOHAN Foundation, Toshniwal Building, 267, Kilpauk Garden Road, Chennai-600010 Tamil Nadu INDIA; Pallavi Kumar (pallavi@mohanfoundation.org), Executive Director, MOHAN Foundation, Sushant Lok-I, Gurugram-122002 Haryana INDIA.

To cite: Sahi MK, Shroff S, Navin S, Kumar P. Organ Commercialism, trafficking and transplant tourism. Indian J Med Ethics. Published online on July 28, 2021. DOI: 10.20529/IJME.2021.056.

Manuscript Editor:Veena Johari

Peer Reviewers: Astrid Lobo Gajiwala and an anonymous reviewer

(c) Indian Journal of Medical Ethics 2021 flourishing organ and tissue commercialism relating to human body parts is intrinsically immoral, and the involvement of the medical community is ethically unacceptable. While one needs to differentiate terms such as organ trafficking, commercialism and transplant tourism*, the underlying basis of organ commerce has always been exploitation of the needy.

\section{International action against commerce in organs}

International transplantation professionals and advocates, along with the World Health Organisation, are committed to fighting organ commercialism, and influencing countries to adopt ethical principles in this field.

\section{The Declaration of Istanbul}

The Declaration of Istanbul on "Organ Trafficking and Transplant Tourism" was the first step to fight such organ commercialism. The meeting issuing the Declaration was held from April 30 to May 1, 2008 in Istanbul, Turkey. The Declaration, for the first time, defined transplant tourism, trafficking and commercialism of organs, and provided ethical guidelines for practice in organ donation and transplantation. Since then, over 100 countries have endorsed the principles of the Declaration. Countries that have subsequently strengthened their laws against the organ trade include Israel, the Philippines, Pakistan and India (3).

The Declaration defined organ trafficking, transplant commercialism and transplant tourism. Organ trafficking was defined as:

... the recruitment, transport, transfer, harbouring or receipt of living or deceased persons or their organs by means of the threat or use of force or other forms of coercion, of abduction, of fraud, of deception, of the abuse of power or of a position of vulnerability, or of the giving to, or the receiving by, a third party of payments or benefits to achieve the transfer of control over the potential donor, for the purpose of exploitation by the removal of organs for transplantation (4).

Transplant commercialism was defined as:

a policy or practice in which an organ is treated as a commodity, including by being bought or sold or used for material gain. Travel for transplantation is the movement of organs, donors, recipients, or transplant professionals across 
jurisdictional borders for transplantation purposes. Travel for transplantation becomes transplant tourism if it involves organ trafficking and/or transplant commercialism or if the resources (organs, professionals and transplant centres) devoted to providing transplants to patients from outside a country undermine the country's ability to provide transplant services for its own population (4).

In 2010, The Transplantation Society (TTS), an international society of professionals involved in transplantation of organs and tissues, and the International Society of Nephrology (ISN), a similar association of nephrologists, created the Declaration of Istanbul Custodian Group (DICG) to disseminate the principles of the Declaration and to respond to new challenges posed by organ trafficking and transplant tourism.

Between February and May 2018, DICG held a consultation to update the Declaration in response to clinical, legal and social developments in the field. The results of the consultation process were presented, reviewed, and adopted as set forth in Madrid in July 2018 during the International Congress of The Transplantation Society (5).

According to the revised Declaration, organ trafficking consists of any of the following activities:

(a) removing organs from living or deceased donors without valid consent or authorisation or in exchange for financial gain or comparable advantage to the donor and/or a third person;

(b) any transportation, manipulation, transplantation or other use of such organs;

(c) offering any undue advantage to, or requesting the same by, a healthcare professional, public official, or employee of a private sector entity to facilitate or perform such removal or use;

(d) soliciting or recruiting donors or recipients, where carried out for financial gain or comparable advantage; or

(e) attempting to commit, or aiding or abetting the commission of, any of these acts.

While "trafficking in persons for the purpose of organ removal is the recruitment, transportation, transfer, harboring, or receipt of persons, by means of the threat or use of force or other forms of coercion, of abduction, of fraud, of deception, of the abuse of power or of a position of vulnerability, or of the giving or receiving of payments or benefits to achieve the consent of a person having control over another person, for the purpose of the removal of organs".

\section{Statements by faith leaders}

The 2014 Joint Declaration of Faith Leaders Against Modern Slavery, and the 2016 Magisterium of Pope Francis at the Judges' Summit on Human Trafficking and Organized Crime also endorsed these efforts.

In 2017 in Rome, 77 key opinion leaders of the international transplant community at the Pontifical Academy of Sciences (PAS), endorsed the following statement:

In accordance with the Resolutions of the United Nations and the World Health Assembly, the 2015 Vatican Summit of mayors from the major cities of the world, stated that organ trafficking and human trafficking for the purpose of organ removal are "true crimes against humanity [that] need to be recognized as such by all religious, political and social leaders, and by national and international legislation," - and we, the undersigned participants of the Pontifical Academy of Sciences Summit on Organ Trafficking, resolve to combat these crimes against humanity through comprehensive efforts that involve all stakeholders around the world (6).

The PAS Summit on Organ Trafficking of the Pontifical Academy of Sciences has made wide-ranging recommendations to governments, ministries of health, judiciaries, religious leaders, professional medical associations, and the general public.

1. That all nations and all cultures recognize human trafficking for the purpose of organ removal and organ trafficking, which include the use of organs from executed prisoners and payments to donors or the next of kin of deceased donors, as crimes that should be condemned worldwide and legally prosecuted at the national and international level.

2. That religious leaders encourage ethical organ donation and condemn human trafficking for the purpose of organ removal and organ trafficking.

3. That nations provide the resources to achieve selfsufficiency in organ donation at a national level -with regional cooperation as appropriate-by reducing the need for transplants through preventive measures and improving access to national transplant programs in an ethical and regulated manner.

4. That governments establish a legal framework that provides an explicit basis for the prevention and prosecution of transplant-related crimes, and protects the victims, regardless of the location where the crimes may have been committed, for example by becoming a Party to the Council of Europe Convention against Organ Trafficking.

5. That healthcare professionals perform an ethical and medical review of living donors and recipients that takes account of their short- and long-term outcomes.

6. That governments establish registries of all organ procurement and transplants performed within their jurisdiction as well as all transplants involving their citizens and residents performed in another jurisdiction, and share appropriate data with international databanks. 
7. That governments develop a legal framework for healthcare and other professionals to communicate information about suspected cases of transplant-related crimes, while respecting their professional obligations to patients.

8. That responsible authorities, with the support of the justice system, investigate transplants that are suspected of involving a crime committed within their jurisdiction or committed by their citizens or residents in another jurisdiction.

9. That responsible authorities, insurance providers, and charities not cover the costs of transplant procedures that involve human trafficking for the purpose of organ removal or organ trafficking.

10. That healthcare professional organizations involved in transplantation promote among their members awareness of, and compliance with, legal instruments and international guidelines against organ trafficking and human trafficking for the purpose of organ removal.

11.That the World Health Organization, the Council of Europe, United Nations agencies, including the United Nations Office on Drugs and Crime, and other international bodies cooperate in enabling a comprehensive ollection of information on transplantrelated crimes, to yield a clearer understanding of their nature and scope and of the organization of the criminal networks involved.

\section{Statements by UN bodies}

Organ trafficking has been condemned and criminalised by the United Nations Protocol against Trafficking in Persons (Palermo Protocol), the Council of Europe Convention against Trafficking in Human Beings, and the Council of Europe Convention against Trafficking in Human Organs. Most countries support these documents in principle. These documents assert that transplant professionals who commit or abet these crimes should be held legally accountable whether the offenses take place domestically or abroad.

These legal instruments are an important link to emerging innovative policy to combat social inequality. Trafficking in human beings for the purpose of organ removal and organ trafficking is contrary to the United Nations General Assembly 2030 Agenda for Sustainable Development (7: para 42). This is an issue of human rights and social justice because the poor are exploited for their organs and yet are not able to receive a transplant if they suffer organ failure. Jeffrey Sachs has written: "Sustainable development argues that economic policy works best when it focuses simultaneously on three big issues: first, promoting economic growth and decent jobs; second, promoting social fairness to women, the poor, and minority groups; and third, promoting environmental sustainability."(6)

\section{The World Medical Association}

Progress has been made by international organisations aligned with the Declaration of Istanbul to curtail organ trafficking. The World Medical Association (WMA) has issued a statement on organ and tissue donation (8). It was adopted by the 63rd WMA General Assembly, Bangkok, Thailand in October 2012 and revised by the 68th WMA General Assembly, Chicago, USA in October 2017. Some key points from the WMA statement are:

- In some parts of the world individuals are paid for donating a kidney, although in virtually all countries the sale of organs is unlawful. The WMA is strongly opposed to a market in organs.

- Transplant surgeons should seek to ensure that the organs and tissues they transplant have been obtained in accordance with the provisions of this policy and should refrain from transplanting organs and tissues that they know, or suspect, have not been procured in a legal and ethical manner.

- National medical associations should work with governments and relevant institutions to ensure that appropriate and effective structures and processes are in place to assess the adherence to ethical and clinical protocols of organ donation and transplantation activities.

\section{Taipei recommendations}

In 2008, the Recommendations on the Prohibition, Prevention and Elimination of Organ Trafficking in Asia (Taipei Recommendations) resulted from the work of the Asia Task Force on Organ Trafficking (9). The Task force which was established by the National Taiwan University, consists of 14 independent expert scholars from the fields of medicine, ethics, law, philosophy and social science. Like the Declaration of Istanbul, the Taipei Recommendations are aimed at making practices in organ donation and transplantation ethical and just, including through reducing vulnerability of persons to organ-related crimes.

\section{SAARC}

India is a key member state of The South Asian Association for Regional Cooperation (SAARC), a regional intergovernmental organisation and geopolitical union of nations in South Asia. SAARC has intermittently taken measures to combat organ trafficking.

\section{Ground realities}

In spite of all these efforts, a number of centres of transplant tourism remain active around the world. Appropriate legislation to curtail these crimes and protect the poor and vulnerable do not exist, or are poorly enforced. These practices also persist because some countries have failed in their responsibility to meet the needs of their citizens related 
to organ transplant and provide resources for development of such a programme.

\section{Organ trafficking and commercialism}

For more than two decades, governments around the world have recognised the need to protect poor people from the exploitation inherent in organ sales. Yet, partly as a consequence of the widespread shortage of organs and the increasing ease of internet communication, organ trafficking and transplant tourism have become global problems. Poverty, unemployment, and the lack of socioeconomic opportunities are factors that make persons vulnerable to organ and human trafficking for the purpose of organ removal. Very often destitute individuals are lured into organ trafficking schemes and induced to sell their organs in the belief that the money will make a substantial difference to their lives. Similarly, desperate patients are willing to pay large amounts and travel to foreign destinations to obtain an organ that may keep them alive, unaware of the short- and long-term health consequences of commercial transplantation.

Unscrupulous brokers and healthcare professionals make organ trafficking possible. The surgical procedures are sometimes performed in unauthorized facilities that clandestinely serve overseas tourists who purchase an organ locally. However, organ commercialism can also occur at legitimate facilities, in situations where individuals who are willing to sell their organs present themselves to transplant centres as a relative or close friend of the recipient who wishes to donate an organ out of altruism. The media have made an important contribution to public awareness by highlighting the plight of trafficked individuals; many independent investigations of transplant-related crimes and corrupt healthcare professionals and unregulated facilities have been published (10).

Over the last 25 years the Internet and the social media have made it easy to advertise, leading people seeking organs to brokers or direct sellers. Some years ago, the auction of a kidney on an e-commerce site, with a bid of USD 5.7 million, was stopped once it came to the notice of the regulators (11).

\section{Tissue commerce}

The use of human tissue has grown exponentially with improvements in procurement, storage, distribution and strict quality checks protocols. It is set to increase in the future (12). Tissue products that are commonly used include bone screws, bone putty, collagen products, acellular dermis (tissue without cells), injectable fascia lata and a range of blood products. In general, there is no scarcity of tissues, because of the availability of synthetic alternatives; any shortage is usually the result of organisational problems and a failure to allocate human and material resources to ensure tissue procurement. Every year hundreds and thousands of processed tissues are stored in large biobanks and utilised for both therapeutic and research purposes.
Tissue commercialisation flourishes unnoticed and today biobanking is a multi-million dollar industry. While solid organ commerce is most prevalent in impoverished countries, commercialisation of body parts such as tissues is prevalent in economically developed countries.

Most national and international laws prohibit both organs and human tissues from sale. But once a tissue becomes a "tissue product", it escapes such regulation (13). For example, tissues removed from patients during surgery may be shipped to biobanks instead of being discarded. Deceased donor tissues may be removed and the family not informed. Sometimes the informed consent document does not mention the intent of such commercial utilisation.

The Transplantation of Human Organs and Tissues Act 1994 in India has penalties for the unauthorised removal of tissues, and making or receiving payment for supplying human tissues (Table 1). However, public knowledge about the practice of transfer of human tissue, especially for commercial use, is very limited (14).

Trafficking in tissues involves not only ethical and legal

Table 1 - Offences and penalties - [Tissue commerce Transplantation of Human Organs and Tissues Act (THOTA) 1994]

\begin{tabular}{|l|l|l|}
\hline Offence & Imprisonment & Fine \\
\hline $\begin{array}{l}\text { Removal of tissues } \\
\text { without authority }\end{array}$ & 3 years & INR 5 lakh \\
\hline $\begin{array}{l}\text { Commercial dealing in } \\
\text { tissues, falsification of } \\
\text { documents }\end{array}$ & $1-3$ years & INR 5 - 25 lakh \\
\hline
\end{tabular}

problems but public health threats as well. If the tissues procured and distributed have not undergone strict quality checks there is a risk of transmitting infectious or tumoral diseases.

Yet, limited attention has been paid to illicit and unethical activities associated with the procurement and clinical use of other substances of human origin, such as tissues. This is perhaps because in society there is less visibility and familiarity with tissue transplantation compared with organ transplantation, although the latter happens far less frequently. Moreover, there is no international agreement on what represents illicit and unethical activities with human tissues, and there is no consensus on which of these practices should be criminalised. Various international guidelines have been developed regarding human tissue, but these are only to set quality and safety standards for their processing, storage and use. A definition of "trafficking in human tissues" needs to be agreed upon at the international level, with the involvement of all stakeholders (15).

\section{The Indian scene}

India has often been a hotspot for organ commerce and exploitation of the poor for organs such as kidneys and more 
recently for part of the liver. The recent 2011 amendments of the law and the Transplantation of Human Organs \& Tissues Rules, 2014, have given the authorisation committee the powers of a civil court. They have shifted the onus of stopping organ commerce on to treating doctors and hospitals. Penalties in the law have been enhanced considerably, as described in Table 2 (16). One example is the Hiranandani kidney case, Mumbai in 2016. For the first time the police arrested not only the brokers but also the designated kidney donor, recipient, transplant coordinator, surgeon and the Chief Executive Officer of the hospital, and the hospital's license was suspended (17). The action also resulted in the tragic death of the recipient, and the donor, who was police custody, had to be rescued by a non-governmental organization (18). For a short time, the transplant community stopped organ transplants in Mumbai in protest (19). However, the police actions did send a strong message to the Indian transplant community.

\section{THOA}

The Transplantation of Human Organs (Amendment) Act, 2011 along with Rules from 2014 has tried to plug loopholes in the 1994 Act and has increased the penalties for violations of the law (Table 2).

Table 2 - Offences and penalties - [Transplantation of Human Organs Act (THOA) 1994 and Transplantation of Human Organs (Amendment) Act, 2011]

\begin{tabular}{|c|c|c|c|c|}
\hline \multirow[t]{2}{*}{ Offence } & \multicolumn{2}{|c|}{ Imprisonment } & \multicolumn{2}{|l|}{ Fine } \\
\hline & THOA 1994 & $\begin{array}{l}\text { THO } \\
\text { (Amendme } \\
\text { nt) Act, } \\
2011\end{array}$ & THOA 1994 & $\begin{array}{l}\text { THO } \\
\text { (Amendme } \\
\text { nt) Act, } \\
2011\end{array}$ \\
\hline $\begin{array}{l}\text { Removal of } \\
\text { organs } \\
\text { without } \\
\text { authority }\end{array}$ & 5 years & 10 years & INR 10,000 & $\begin{array}{l}\text { INR } 20 \text { lakh } \\
\text { USD 40,000 }\end{array}$ \\
\hline $\begin{array}{l}\text { Removal of } \\
\text { organs } \\
\text { without } \\
\text { authority by } \\
\text { RMP }\end{array}$ & $\begin{array}{l}\text { 1st offence: } \\
\text { de- } \\
\text { registration } \\
\text { for } 2 \text { years }\end{array}$ & $\begin{array}{l}\text { 1st offence: } \\
\text { de- } \\
\text { registration } \\
\text { for } 3 \text { years }\end{array}$ & $\begin{array}{l}\text { 2nd offence: } \\
\text { permanent } \\
\text { de- } \\
\text { registration }\end{array}$ & $\begin{array}{l}\text { 2nd offence: } \\
\text { permanent } \\
\text { de- } \\
\text { registration }\end{array}$ \\
\hline $\begin{array}{l}\text { Commercial } \\
\text { dealing in } \\
\text { organs, } \\
\text { falsification } \\
\text { of documents }\end{array}$ & 2-7 years & 5-10 years & $\begin{array}{l}\text { INR 10- } \\
20,000\end{array}$ & $\begin{array}{l}\text { INR } 20 \text { lakh - } \\
1 \text { Crore USD } \\
40,000- \\
150,000\end{array}$ \\
\hline $\begin{array}{l}\text { Any violation } \\
\text { of THOA }\end{array}$ & 3 years & 5 years & INR 5,000 & $\begin{array}{l}\text { INR } 20 \text { lakhs } \\
\text { USD 40,000 }\end{array}$ \\
\hline
\end{tabular}

However, unscrupulous elements over the years have found ways to exploit the law and the systems.

There are 12 different consent forms for living donation and transplantation in the Rules to cover the various provisions. All procedures are minutely detailed. Most authorisation committees of both government and private hospitals require video recording of the donor and recipient interviews in which they pledge that no money or other benefit has been exchanged for the purpose of organ donation, and that organ donation is purely out of affection or attachment.

The consent form from the donor is an affidavit which includes statements that the donor understands that organ sale is a crime; she/he has not been paid for donation, and the donation is given with informed consent. The form is required to be signed by a notary.

The procedure of living donation prescribed by the law is described in Flowchart I.

The 2011 transplant law allows a foreigner to get an organ from an Indian donor only if they are near relatives, and with the prior approval of the Authorisation Committee. However, it does not prevent foreigners from getting a transplant if they can bring their own (foreign) organ donor, along with an undertaking from their embassy that there is no commercial intent. These foreigners are required to go through the same government Authorisation Committee as an Indian unrelated pair does. The same process is followed of document scrutiny and interview of the prospective donor and recipient. Due to the lack of transplant programmes in many developing countries and the cost advantage of India, many patients travel to India for such transplants. Despite the systems in place some paid donors have escaped undetected. One reason for this is that some have come with their embassy's certification of the relationship between donor and recipient. There have also been instances where large hospital chains have employed marketing personnel to advertise their services among local doctors; some inducement may have been offered as patient referral fees. Such practices if brought to light with evidence are punishable offences as per the Indian law.

Tissue banking and THOTA: Tissue banking in India has been brought under the ambit of the Transplantation of Human Organs and Tissues (THOTA) Act in 2011 (20). The bulk of such donations is of corneas. Other tissue donations such as skin, bones, fascia and others are very limited, with less than half a dozen such biobanks in the country. The National Organ and Tissue Transplant Organisation has been given the mandate to establish a centralised national facility

The Indian Penal Code: The Indian Penal Code: Organ commerce is also covered in The Indian Penal Code (IPC). Chapter XVI covers Offences Affecting Life and includes 'forced removal of organs' as a crime of exploitation. The definition of 'exploitation' is relevant because the Act defines trafficking as a series of acts committed for the purpose of exploitation.

While The UN Protocol related to transnational organized crime and corruption which India ratified in 2011 defines "exploitation: as:"Exploitation shall include, at a minimum, the exploitation of the prostitution of others or other forms of sexual exploitation, forced labour or services, slavery or practices similar to slavery, servitude or the removal of organs;..."; 


\section{Flowchart I: Living donation procedure as given in THOTA}

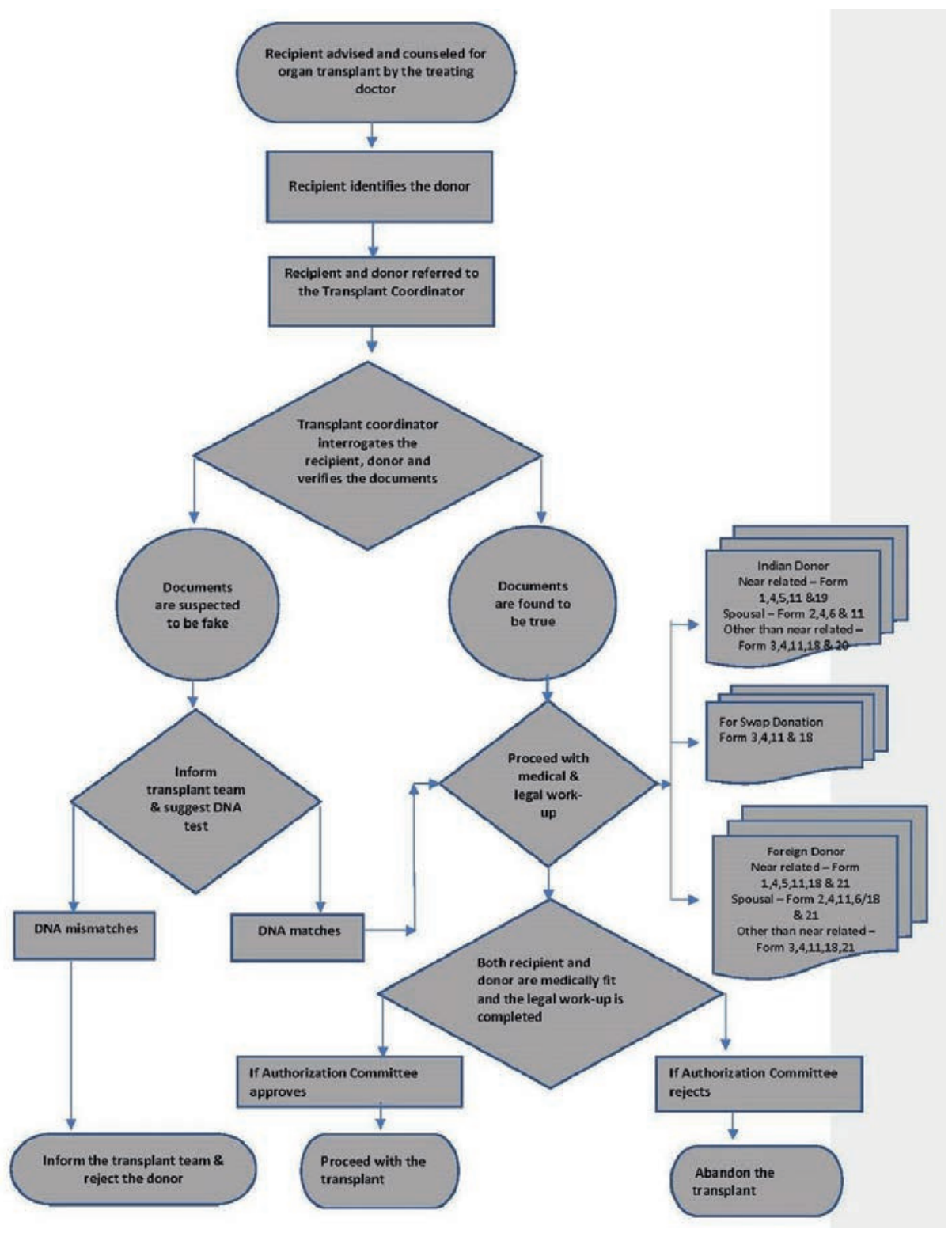

Under Section 370 IPC "exploitation" is defined as: "The expression "exploitation" shall include, prostitution or other forms of sexual exploitation, forced labour or services, slavery or practices similar to slavery, servitude, or the forced removal of organs" (21). The offence of trafficking is punished with rigorous imprisonment for a term which shall not be less than seven years, but which may extend to 10 years, and shall also be liable to fine. When a public servant (a doctor who is in service or pay of the government) is involved in the trafficking of any person then, such public servant shall be punished with imprisonment for the remainder of that person's natural life and shall also be liable to fine (22).

Despite these measures there have been instances of organ sale and, data from the National Crime Record Bureau shows that few cases have been registered under the law. In 2014, 2 cases were reported but no arrests were made (23). The number went up to 15 in 2015 (24) and down to seven in
2016 (25). Vigilance and cooperation is required from the transplant community in India to wipe out this trade.

\section{The deceased organ transplantation programme}

Organ trafficking in India is also a deterrent to the development of a meaningful solution to the organ shortage, in the form of a successful deceased donor transplantation programme. A robust deceased donation programme can help combat the organ trade. Moreover, trust in a nation's deceased organ donation programme builds public revulsion to organ trafficking (26).

In the last decade, there has been a growth in deceased organ donation, not only of kidneys but also of the liver, heart and lungs. The authors are associated with MOHAN Foundation, a non-profit organisation in India that has worked for the cause of deceased donation for the past 23 years. MOHAN Foundation has a memorandum of 
understanding with the National Health Service Blood and Transplant of the UK with the objective of improving the organ donation rates in both countries, and developing best practices in the field of organ donation and transplantation.

Deceased organ allocation: The law also outlines guidelines and protocols for organ allocation. Tamil Nadu was the first state in India to establish a transparent and equitable webbased organ sharing system through a government order in 2008. It also performed kidney and liver transplants for economically underprivileged patients in government hospitals free of cost. Maharashtra, Karnataka, Kerala, Telangana, Andhra Pradesh and Rajasthan have organ sharing networks (27).

Eye banks: There are currently 370 functional eye banks (28) in the country, and the government incentivises nongovernmental organisations and societies for facilitating eye donation through a cash award of Rs 2,000/- per pair of eyes for each donation (29). The eye donation rate in India currently is around 29 per million population (PMP). There have been no commercial scandals related to tissue banking or distribution in India.

\section{Conclusion}

Organ trafficking is a crime against humanity, a stand endorsed by international bodies, professional associations, faith-based organisations, and the international transplant community. While they have concentrated their efforts on curbing organ commerce which flourishes in developing countries, tissue commerce has been happening in developed countries.

The Internet and the proliferation of social media has created new challenges to the fight against organ commerce. Local vigilance bodies must be linked together through a global watchdog to curb this ever-growing menace.

Amendments to the Indian law on transplants address some of the major roadblocks in its implementation and recent reports shows a decrease in organ commerce here. Countries where organ commerce is a major problem must set up an independent oversight committee with powers to combat these practices.

*Note: Transplant tourism is the practice of patients travelling abroad for transplants, whether with a commercial intent or when there is a genuine relationship between the foreign donor and the recipient. The word transplant tourism is derived from the word medical tourism which is defined by CDC (32) as follows -"Medical tourism" refers to traveling to another country for medical care, because of cost, or availability. International bodies must differentiate between transplant tourism which is derives from medical tourism and 'transplant travel for organ commerce' where there is a commercial intent.

\section{References}

1. Shimazono $Y$. The state of the international organ trade: a provisional picture based on integration of available information. Bull World Health Organ. 2007 Dec;85(12):901-80.
2. Pirnay JP, Vanderkelen A, Ectors N, Delloye C, Dufrane D, Baudoux E, et al. Beware of the commercialization of human cells and tissues: situation in the European Union. Cell Tissue Bank. 2012 Aug 1;13(3): 487-98.

3. Wikipedia. Declaration of Istanbul. 2020 updated 2020 May 9 [cited 2020 Jul]. Available from: https://en.wikipedia.org/wiki/ Declaration_of_Istanbul

4. The Declaration of Istanbul on Organ Trafficking and Transplant Tourism. Indian J Nephrol. 2008 Jul;18(3): 135-40.doi: 10.4103/09714065.43686.

5. Muller E, Dominguez-Gil B, Martin DE. The Declaration of Istanbul on Organ Trafficking and Transplant Tourism (2018 Edition) Introduction. Transplantation. 2019 Feb:103(2): 217. doi: 10.1097/TP. 0000000000002541

6. Statement of the Pontifical Academy of Sciences Summit on Organ Trafficking and Transplant Tourism. Int J Organ Transplant Med. 2017; 2 (2): 33-34.

7. United Nations Organisation. Transforming our world: the 2030 Agenda for Sustainable Development. Geneva: UNO; 2015 Sep[cited $2021 \mathrm{Jul}$ 15]. Available from: https://sdgs.un.org/2030agenda

8. World Medical Association. WMA Statement on Organ and Tissue Donation [Internet]. France: WMA; 2017 Oct 17[cited 2020 Jul 20] Available from: https://www.wma.net/policies-post/wma-statementon-organ-and-tissue-donation/

9. United Nations Office on Drugs and Crime. Assessment Toolkit: Trafficking in persons for the purpose of organ removal. Vienna: UNODC; 2015[cited 2020 Jul 20]. Available from: https:// www.unodc.org/documents/human-trafficking/2015/

UNODC_Assessment_Toolkit_TIP_for_the_Purpose_of_Organ_Remo val.pdf

10. Riella MC. Declaration of the Vatican Pontifical Academy of Sciences. J Bras Nefrol. 2017 Sep;39(3):236-8.

11. Perrotta K. EBay pulls the plug on $\$ 5.7 \mathrm{M}$ human kidney [Internet]. New York Post.1999 Sep 3[cited 2020 Jul 20]. Available from: https:// nypost.com/1999/09/03/ebay-pulls-the-plug-on-5-7m-humankidney/

12. Caplan A, Dominguez-Gil B, Matesanz R, Prior C. Trafficking in organs, tissues and cells and trafficking in human beings for the purpose of the removal of organs. Joint Council of Europe/United Nations Study. 2009[cited $2020 \mathrm{Jul}$ 20]. Available from: https://rm.coe.int/ $16805 \mathrm{ad} 1 \mathrm{bb}$

13. Tonti-Filippini N. Commercialization of Human Tissue Products. J Transplant Technol Res. 2013;3(2): e123. doi:10.4172/21610991.1000e123

14. Lenk $\mathrm{C}$, Beier K. Is the commercialisation of human tissue and body material forbidden in the countries of the European Union? J Med Ethics. 2012 Jun 1;38(6):342-6.

15. Illicit and Unethical activities with human tissues and cells: Addressing the need for the elaboration of an international legal instrument to protect donors and recipients. Council of Europe. 2018 Oct 12 [cited $2020 \mathrm{Jul}$ 20]. Available from: https://www.edqm.eu/ sites/default/files/position_paper_-

_illicit_and_unethical_activities_with_human_tissues_and_cells_rev -_november_2018.pdf

16. National Organ and Tissue Transplant Organisation, Government of India. Transplantation of Human Organs Act, 2011. The Gazette of India: Extraordinary Part II-Section 1, Notification dated 27th September 2011. New Delhi: NOTTO; 2011[cited 2020 Jul 20]. Available from: https://notto.gov.in/WriteReadData/Portal/images/ THOA-amendment-2011.pdf

17. Khan H. Mumbai kidney racket: Hiranandani hospital's transplant license suspended [Internet]. News Nation. Aug 10, 2016[cited 2020 Jul 20]. Available from: https://english.newsnationtv.com/india/news/ mumbai-kidney-racket-hiranandani-hospitals-transplant-licensesuspended-142337.html

18. Hackim S. 'I'm a victim of organ trafficking, not a criminal'. Mumbai Mirror. Updated 2019 Mar 19 [cited 2020 Jul 20]. Available from: https://mumbaimirror.indiatimes.com/mumbai/crime/im-a-victimof-organ-trafficking-not-a-criminal/articleshow/68473716.cms

19. Ailawadi A Kidneys for sale: The Great Indian Scam [Internet]. Bloomberg Quint. 2016 Aug 23[cited 2020 Jul 20]. Available from: https://www.bloombergquint.com/business/kidneys-for-sale-thegreat-indian-scam

20. Sahay M. Transplantation of Human Organs and Tissues Act"Simplified". Indian J Transplant. 2018 Apr 1;12(2):84

21. Pai A. Indian Penal Code Amendments and advocacy to prevent conflation of trafficking and sex work, Section 370. 2013 Feb [cited 2020 Jul 20]. Available from: http://www.sangram.org/resources/ 
Amending-section-370-IPC-verma-commission-clarifies-intentionbehind-legislation.pdf

22. Devgan R. IPC Chapter 16: Indian Penal Code1860. Updated 2018 Sep 2 [cited 2020 Jul 20]. Available from: http://devgan.in/ipc/ chapter_16.php

23. National Crime Records Bureau, Ministry of Home Affairs. Crime in India 2014. Statistics. New Delhi: NCRB; 2015 Jul 8 [cited 2020 Dec 22]. Available from: https://ncrb.gov.in/sites/default/files/Statistics/ Statistics\%202014.pdf

24. National Crime Records Bureau, Ministry of Home Affairs. Crime in India 2015 Statistics [Internet]. New Delhi: NCRB; 2016 Jul29[cited 2020 Jul 20]. Available from: https://ncrb.gov.in/sites/default/files/ Statistics/Statistics-2015 rev1_1.pdf

25. National Crime Records Bureau, Ministry of Home Affairs. Crime in India 2016 Statistics. New Delhi: NCRB; 2017 Oct 10[cited 2020 Jul 20]. Available from: https://ncrb.gov.in/sites/default/files/ Crime\%20in\%20India\%202016\%20-\%20Full\%20Publication.pdf

26. Campbell F. Deceased donation combats organ trafficking. Indian
Transplant Newsletter. 2017 Mar-Jun;16 (50) [cited 2020 Jul 20]. Available from: https://www.itnnews.co.in/indian-transplantnewsletter/issue50/Deceased-Donation-Combats-Organ-Trafficking499.htm

27. Abraham G, Vijayan M, Gopalakrishnan N, Shroff S, Amalorpavanathan J, Yuvaraj A. State of deceased donor transplantation in India: A model for developing countries around the world. World J Transplant. 2016 Jun 24;6(2):331-5. Doi: 10.5500/ wjt.v6.i2.331.

28. Shroff S, Navin S. The Giving Indian. Indian Transplant Newsletter. 2019 Mar-Jun;18 (56).[cited 2020 Jul 20]. Available from: https:// www.itnnews.co.in/indian-transplant-newsletter/issue56/TheGiving-Indian-904.htm

29. National Programme for Control of Blindness and Visual Impairment. Schemes for implementation of National Programme for Control of Blindness and Visual Impairment (NPCBVI); 2017-2020. New Delhi: NPCBVI; 2018 Dec[cited 2020 Jul 20]. Available from: https:// www.daman.nic.in/nhm/documents/2019/664-22-02-2019.pdf 